\title{
DISINFESTATION OF COWPEA BEETLE IN SOME STORED PULSES USING MICROWAVE ENERGY
}

\author{
SHOUGHY, M. I. ${ }^{1}$ and H.M. ELZUN ${ }^{2}$ \\ 1. Agric. Eng. Res. Ins. (AEnRI), Dokki, Giza, Egypt. E-Mail: \\ Shoughy_AERI@Yahoo.com \\ 2. Plant Protection Res. Inst., Agric. Res. Center, Giza.
}

(Manuscript received the $1^{\text {st }}$ January 2014)

\begin{abstract}
Dried pulses such as fababean and cowpea are the larger consumed seeds as a protein sources in Egypt and the developing nations, unfortunately, they are infested by several insects from which is Cowpea beetle(Callosobruchus maculatus, F.). A multiple microwave power oven operating at $2.45 \mathrm{GHz}$ and $1000 \mathrm{~W}$ output power at various power levels and exposure times was used in this study to determine their effect on all life stages of $C$. maculatus in fababean and cowpea seeds. Pulses samples of $100 \mathrm{~g}$ was infested with stored-pulse insect $C$. maculatus at all life stages and then exposed to microwave energy at four power levels $200,400,600$ and $800 \mathrm{~W}$ at three exposure times of 20,30 and 40s. The effect of microwave treatments on an insect lethal temperature and adult's mortality, egg hatchability and reduction of their progeny for all life stages and seed quality was evaluated. The average insect lethal temperatures of cowpea and fababean at 400W, 30s, 400W, 40s, $600 \mathrm{~W}, 20 \mathrm{~s}$ and $600 \mathrm{~W}, 30 \mathrm{~s}$ were around $52,55,58$ and $60 \pm 1.5^{\circ} \mathrm{C}$, respectively. The adult mortality and their reduction of progeny increased and egg hatchability decreased significantly in the infested cowpea and fababean seeds with an increase in power level or exposure time or both. Complete adults mortality (100\%) and reduction of their progeny were achieved for all $C$. maculatus life stages in cowpea seeds at $600 \mathrm{~W}$ for an exposure time of $20 \mathrm{~s}$ or at $400 \mathrm{~W}$ for an exposure time of 30 s. While, in fababean seeds the mortality was achieved at $600 \mathrm{~W}, 30 \mathrm{~s}$ or at $400 \mathrm{~W}$ and 40 s exposure time, except for pupal stage which was obtained at $800 \mathrm{~W}$ and $20 \mathrm{~s}$ or at $600 \mathrm{~W}$ and $30 \mathrm{~s}$ exposure time. Among the life stages of $C$. maculatus in pulses, eggs were the most susceptible to the microwave energy followed by larval, adults and the least susceptible was the pupal. Disinfestation of insects using microwaves did not leave undesirable residues and meanwhile, reduces insect reproduction. There was no significant difference in the protein content of microwave-treated and control pulses, while the seed germination percentage significantly reduced.
\end{abstract}

\section{INTRODUCTION}

Stored grain infestations is a very serious problem, as various life stages of insects cause economic damage and deteriorate the quality of food grains, legumes and food products. Pulses are the dry, edible seeds of legume plants. Insect control is 
essential for storing grains and pulses successfully. Cowpea and fababean seeds are consumed in different forms as they provide important vitamins, phyto-nutrients including antioxidants besides protein, carbohydrates, minerals and trace elements (Zia-UL-Haq et al., 2010). A major problem in the marketing of these pulses and their products are infestation by insect pests. The overall damage caused by these insect pests in pulses, worldwide is estimated to be $10-40 \%$ annually (Upadhyay and Ahmad, 2011). Typically, chemical fumigants are used to disinfest product, but regulatory issues, insect resistance, environmental concerns and the expansion of the organic market have caused the industry to explore non-chemical alternatives (Vadivambal et al., 2010 and Abo-El-Saad et al., 2011). There is a great need to develop alternative environmentally friendly disinfestation methods to replace the typical chemical disinfestation methods. Temperature treatment of stored grains is a best physical method which successfully kills several life stages of insects at a time. However, the disadvantages of conventional thermal disinfestation method include a slow heating rate, a long processing time and non-uniform temperature distribution. It was also impairs the flavor and appearance of the treated product and reduces its palatability and acceptability to consumers. Microwave disinfestation is also a physical method to control insects in stored grain (Vadivambal, 2009). Microwaves are electromagnetic waves with frequencies ranging from about $0.3 \mathrm{GHz}$ to $3 \mathrm{GHz}$ and corresponding wavelength from 1 to $0.001 \mathrm{~m}$. For common household applications and industrial purposes, only $2.45 \mathrm{GHz}$ is permitted (Guo et al., 2009). Microwave radiation, with good penetrability, can kill pests existing in grain kernels. Hazardous impacts could be due to a high oscillation frequency of water molecules in the body of insects. One possible alternation is the use of microwave energy in food processing applications mainly due to its ability to cause fast internal heating products to insecticidal levels, no chemical residues left in the food and hence there are no adverse effects on human beings, on the environment and the insects are unlikely to develop resistance to this treatment. Varith and Kiatsiriroat (2004) studied the microwave heating on mangoes with $2.45 \mathrm{GHz}$ and $800 \mathrm{~W}$ microwave power oven and observed an increase of internal temperature up to $46^{\circ} \mathrm{C}$ within $40 \mathrm{~s}$. They reported that oriental fruit fly eggs were effectively disinfested with temperatures higher than $48^{\circ} \mathrm{C}$ after a minimum holding time of $2 \mathrm{~min}$ and the heat distribution inside the mangoes depended on mango orientation, microwave power and exposure time. Effects of the thermal process depend on the working parameters of the applied devices and qualitative traits of the processed materials. Up to date, these issues have not been fully solved and they require further intensified studies. It is necessary to study the effect of microwave energy on attributes of pulses quality to establish 
hypothetical quality changes in order to use microwave energy as an alternative method of pest control.

The objectives of this study were to determine the adults mortality, egg hatchability and reduction of their progeny of life stages (egg, larval and pupal) of cowpea beetle, C. maculatus in infested dried pulses (fababean and cowpea) at four microwave power levels (200,400, 600 and 800W) and at three exposure times (20, 30 and 40s) and to determine the change of seed surface temperature, protein content and germination percentage during microwave treatments.

\section{MATERIALS AND METHODS}

\section{Microwave heating treatments:}

Microwave processing was carried out in a multiple microwave power oven, LG model (MS-3948ASC), applying radiation of $2.45 \mathrm{GHz}$ frequency at $1000 \mathrm{~W}$ maximum output power as shown in Plate 1 . The microwave oven consisted of a magnetron, waveguide, stirrer and a turntable glass plate with $323 \mathrm{~mm}$ diameter at the base of the oven cavity, as shown in Fig. 1. Table (1) shows the technical specifications of used multiple power microwave oven. It has the capability of operating at five output power levels, 100, 200, 400, 600, 800 and 1000W to give maximum flexibility and control over heating. The exposure time was set by timer beginning from 10s. To increase the effect of uniform heating, microwave ovens are normally equipped with a mode stirrer. The mode stirrer is just a metallic fan blade, which is used to perturb the field distribution through openings inside the oven cavity. The sample is also rotated with a motorized platter to increase the uniformity of heating by reducing concentration of the power at certain places (Nishkaran, 2002). The $100 \mathrm{~g}$ samples of cowpea and fababean infested with insect $C$. maculatusand their life stages were placed on a Birex dish centrally on the turntable plate in the base of heating chamber of the device and exposed to microwave for various duration time. Since the metallic thermocouple make restricted of microwave radiations, just after each exposure time, the surface temperature of the pulses seeds was recorded by inserting the bulb of a thermometer inside the seeds. Twelve variants of seed treatments of each pulse type were prepared, in which three exposure times (20, 30 and 40s) corresponded to each of four microwave power levels (200, 400, 600 and $800 \mathrm{~W}$ ) with $12.5 \pm 0.2 \%$, wet basis, seeds moisture content. Each set of experiments was repeated three times. 


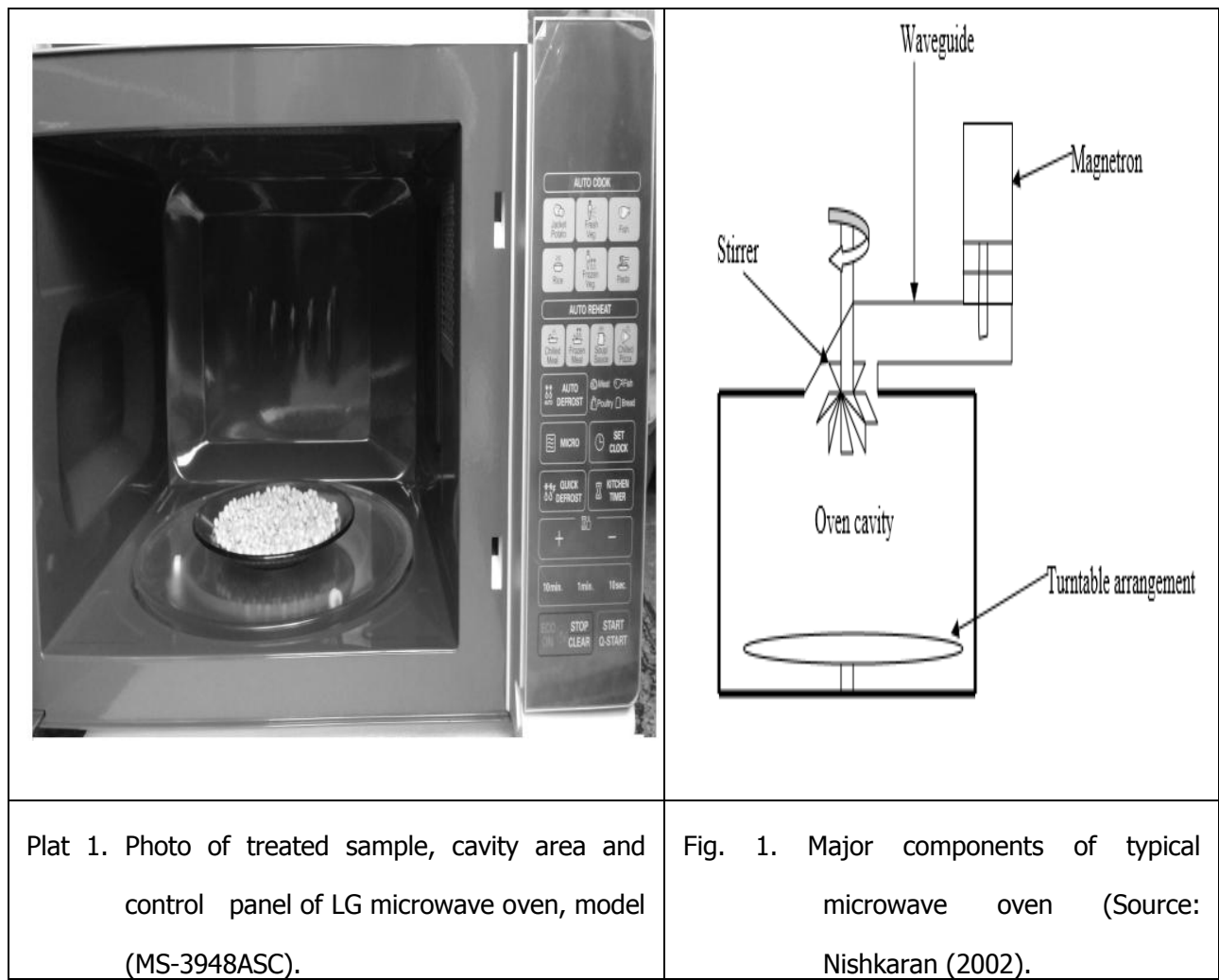

Table 1. Technical specifications of used multiple power LG microwave oven:

\begin{tabular}{|c|c|c|}
\hline Item & \multicolumn{2}{|c|}{ Specification } \\
\hline Type & \multicolumn{2}{|l|}{ LG , China } \\
\hline Model & \multicolumn{2}{|l|}{ (MS-3948ASC) } \\
\hline Power Input & \multicolumn{2}{|l|}{$230 \mathrm{VAC} / 50 \mathrm{~Hz}$} \\
\hline Power Output & \multicolumn{2}{|c|}{ 1000W (IEC60705 rating Standard) } \\
\hline Power Levels & \multicolumn{2}{|c|}{ 5Levels $(20,40,60,80$ and $100 \%)$} \\
\hline Timer Ranges & $--\min$. & -- sec. \\
\hline Microwave Frequency & \multicolumn{2}{|l|}{$2450 \mathrm{MHz}$} \\
\hline \multicolumn{3}{|l|}{ Power consumption } \\
\hline Microwave & \multicolumn{2}{|l|}{ 1450Watts } \\
\hline Outside Dimensions (W $\times \mathrm{H} \times \mathrm{D})$ & \multicolumn{2}{|c|}{$550 \mathrm{~mm} \times 320 \mathrm{~mm} \times 426 \mathrm{~mm}$} \\
\hline Oven Cavity & \multicolumn{2}{|l|}{$370 \times 260 \times 360 \mathrm{~mm}$} \\
\hline Volume & \multicolumn{2}{|l|}{ 39Litre } \\
\hline Weight & \multicolumn{2}{|l|}{$25 \mathrm{~kg}$} \\
\hline
\end{tabular}

\section{Pulses samples preparation:}

The fababean (Visia faba L.), Misr 1 cultivar and cowpea (Vigna unguiculata L.), Dokki 331 cultivar were used for the experimental study. Table 2 shows some physical properties of used fababean and cowpea seeds. The sound fababean, sound and infested cowpea seeds and life stage cycle of $C$. maculatus. Moisture content of 
the sample was determined by drying $10 \mathrm{~g}$ of unground seed, in triplicate at $130^{\circ} \mathrm{C}$ for 20h AOAC (2005) in a precision hot air oven and expressed on a wet mass basis. The initial moisture content of fababean was $12.5 \%$ (wet basis) and for cowpea was $12.3 \%$. The seeds were sterilized by freezing at $-18^{\circ} \mathrm{C}$ for one week to kill any prior insect infestation and then stored in sealed polyethylene bags at $5^{\circ} \mathrm{C}$ until required for experiments.

Table 2. Some physical properties of used sound fababean and cowpea seeds.

\begin{tabular}{|l|c|c|c|c|c|c|c|c|}
\hline Seeds & $\mathrm{L}, \mathrm{mm}$ & $\mathrm{W}, \mathrm{mm}$ & $\mathrm{T}, \mathrm{mm}$ & $\mathrm{M}, \mathrm{g}$ & $\mathrm{d}_{\mathrm{g}}, \mathrm{mm}$ & $\mathrm{d}_{\mathrm{a}}, \mathrm{mm}$ & $\mathrm{S}_{\mathrm{p}^{\prime}} \%$ & $\mathrm{MC} \%, \mathrm{wb}$ \\
\hline $\begin{array}{l}\text { Fababean* } \\
\text { (Misr 1) }\end{array}$ & 13.6 & 10.1 & 6.29 & 0.63 & 10.1 & 11.5 & 0.71 & 12.5 \\
\hline $\begin{array}{l}\text { Cowpea** } \\
\text { (Dokki 331) }\end{array}$ & 9.2 & 6.5 & 5.5 & 0.32 & 6.9 & 7.1 & 0.75 & 12.3 \\
\hline
\end{tabular}

L: length, W: width, T: thickness, M: mass, $d_{g}$ : geometric dia., $d_{a}$ : arithmetic dia., $S_{p}$ : spherically, and MC: moisture content dry basis.*Shoughy and Amer (2006), **Zaalouk and Ghanem (2003).

\section{Infestation methods of pulses:}

Determination of mortality of pulses insects was evaluated as described by Vadivambal, (2009). Cowpea and fababean were being considered as surrogate host pulses to be infested by cowpea beetles to validate microwave treatment in this study. The original strain of tested insect cowpea beetle, $C$. maculatus the most common storage insect in pulses seeds, was obtained from the Department of Stored Product Pests, Plant protection Research Institute, Agricultural Research Center, Dokki, Egypt after they were collected from naturally infested cowpea seeds. Newly emerged adults ( 0 -24hrs old) were used in the experiments. The tested insects were reared at $25 \pm 1^{\circ} \mathrm{C}$ and $65 \pm 2 \%$ relative humidity $(\mathrm{RH})$ on cowpea seeds. Before the disinfestation tests, each $100 \mathrm{~g}$ pulses samples were infested with 20 pair adults of $C$. maculatus.Infested seeds were treated $2,7,15$, and 21days after infestation when developing cowpea beetles were in the egg, larval, pupal and adult stage, respectively. The treated samples contained both adult insects and their life stages at the time of disinfestation treatment using multiples microwave power oven. Treated samples were held for adult emergence. In order to obtain the adults, the culture medium was sieved to remove the old weevils therein and the newly emerged insects were collected for experiments. The sensitivity of eggs (0-72 hrs. old), larval ( 1 week old), pupal (3days old) and adult is (0-24hrs. old) were tested.

\section{Determination of insect's disinfestation:}

\section{Adult's treatments:}

One hundred gram sample from each pulse seeds was placed in the Birex dish and 20 pairs of adult insects were added to the sample in each dish. The oven was 
switched on and the power adjusted to the desired level. The seeds, along with the insects, were then kept in Birex dishes on the rotating turnplate and the samples were subjected to microwave energy. When the treatment completed, the dishes containing the infested seeds was gently taken out and the samples were spread on a sheet of paper. The numbers of alive and dead insects were counted. The adult insects were considered dead if they failed to respond to gentle rubbing with a small brush. The sample was allowed to cool and the insects were checked for mortality again after $15 \mathrm{~min}$. A minimum of three replicates were done for all the mortality experiments. Non-exposed replicates were used as control, Vadivambal, (2009).

\section{Immature life stages treatments:}

\section{Eggs treatments:}

To determine the hatchability of the egg stage, the seeds along with the eggs were treated with microwave energy and then returned to favorable environment, where surviving eggs can develop into larval. The white eggs are glued to the outside of fababean or cowpea and are clearly visible as small white dots on the seeds. After exposure, dishes were placed inside the incubator at $25 \pm 1^{\circ} \mathrm{C}, 65 \pm 2 \% \mathrm{R} . \mathrm{H}$. as mentioned before for two weeks, then hatchability percentage was calculated. After two weeks, the numbers of larval emerging from the eggs were counted. The transparent eggs were considered unfertilized or unhatched or eggs with dead embryos or larval while the opaque eggs were those from which larval had been hatched and penetrated into the seeds. The same previous methods were carried out without exposure to microwave for control treatment. The egg hatchability was counted as follows (Elzun et al., 2012):

$$
\text { Hatchability, } \%=\frac{\text { No. of egg hatched }}{\text { No. of total egg laid }} \times 100
$$

\section{Larval treatments:}

Because the larval and pupal stages of $C$. maculatus are internal of the seeds, the mortality of them was considered by their reduction of progeny. For the larval stage, the experiments were conducted in the same way as for the adult insects. The eggs laid on the seeds were placed inside the incubator under the laboratory conditions until hatching and exposed to microwave treatments. After exposure, dishes were placed inside the incubator (at $25 \pm 1^{\circ} \mathrm{C}, 65 \pm 2 \%$ R.H.) until adult emergence. The control mortality for larval was determined by allowing the infested seeds without exposure to microwave energy and the reduction of larval progeny was determined immediately as in adults. 


\section{Pupal treatments:}

For pupal stage, the eggs laid on the seeds were placed inside the incubator under the laboratory conditions and left to reach to pupal stage (3days old). The pupal were subjected to microwave energy and returned to the favorable environment $\left(25 \pm 1^{\circ} \mathrm{C}\right.$ and $\left.65 \pm 2 \% \mathrm{RH}\right)$. After ten days, the total number of adults that emerged from pupal was counted (Vadivambal, 2009). The control mortality of pupal was determined by allowing the grain along with the eggs and pupal to the same favorable environment and checked after two weeks and 10 days, respectively for larval and adult emergencies. The reductions of progeny for $\mathrm{C}$. maculatus all life stages were counted as follows (Elzun et al., 2012):

$$
\text { Reduction of progeny, } \%=\frac{\text { No. of progeny of control }- \text { No. of progeny of treatment }}{\text { No. of progeny of control }} \times 100 .
$$

\section{Determination of protein content and germination percentage:}

The nitrogen content was estimated by the micro-Kjeldahl method and the crude protein was calculated as ( $\mathrm{N} \times 6.25)$ as described by AOAC (2005). The quality tests were done on control samples and the samples were treated at 600W, 20 and $30 \mathrm{~s}$, for $400 \mathrm{~W}, 30$ and $40 \mathrm{~s}$ and for $800 \mathrm{~W}$ and $20 \mathrm{~s}$ for two pulses because complete mortality of all life stages was obtained at these power levels and exposure times. Germination of seeds subjected to different levels of microwave power and exposure time was assessed by plating 25 seeds on Whatman No. 3 filter paper in a $7-\mathrm{cm}$ diameter Petri-dish saturated with distilled water, Vadivambal (2009). The plates were placed in a plastic bag to prevent desiccation of the filter paper and kept in an incubator at $25^{\circ} \mathrm{C}$ for 7 days. On the seventh day, the germinated seeds were counted and the germination percentage was calculated. Three replications were done for all the samples.

\section{Data analysis}

Experimental design was randomized block design. The analysis of variance was done at $95 \%$ confidence interval and LSD was evaluated.

\section{RESULTS AND DISCUSSIONS}

\section{Pulses temperatures at different power levels and exposure times:}

Fig. 2 shows the pulses temperatures with different power levels and exposure times. At the same microwave power of $200 \mathrm{~W}$, the samples treated for 20 , 30 and 40 s reached to the corresponding temperatures of $36.7,42.5$, and $51.1^{\circ} \mathrm{C}$, for fababean and $38.7,45.6$, and $53.8^{\circ} \mathrm{C}$ for cowpea, respectively. When increasing power levels and exposure time or both, the seed temperature increased. The average temperatures of fababean and cowpea at $600 \mathrm{~W}$ and $20 \mathrm{~s}$ were around 52 and $56.2^{\circ} \mathrm{C}$, 
respectively. The average temperatures of fababean and cowpea at $400 \mathrm{~W}$ and $30 \mathrm{~s}$ were around 54 and $57.5^{\circ} \mathrm{C}$, respectively. Meanwhile, there are $1.5-4.5^{\circ} \mathrm{C}$ increases of cowpea seeds temperature more than fababean seeds at the same microwave treatment due to the difference of the seed size and shape as shown earlier in Table 2. When heating grains using microwaves, care should be taken to keep the maximum temperature at $60^{\circ} \mathrm{C}$, otherwise the seeds will become not viable, while one hundred percent mortality of stored-grain insects was achieved using microwave energy as reported by Vadivambal et al., (2008). Such temperatures could initiate the denaturation of enzymes, proteins, nucleic acids, as well as the disruption of membranes of insects sells, causing the basis of cell damage thermally to become hard to distinguish. Also, the end use quality of treated seeds is not affected until they are held at around $60^{\circ} \mathrm{C}$ as reported by Vadivambal, et al., (2010).

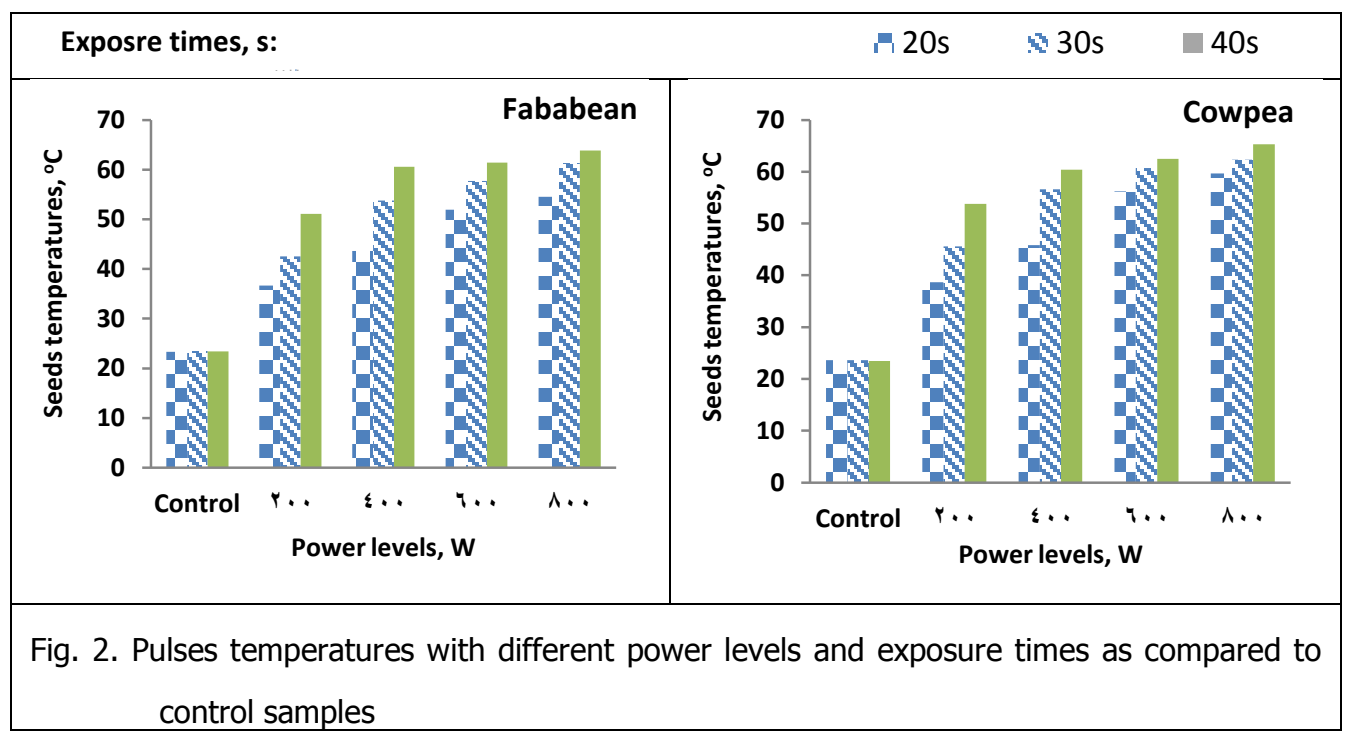

\section{Egg hatchability and reduction in $\boldsymbol{C}$. maculatus progeny in pulses:}

Effect of microwave power levels on the egg hatchability and reduction of their progeny of $C$. maculatus infested fababean and cowpea seeds at three exposure times were studied and the results are shown in Fig. 3. There was a gradual reduction in hatchability with increasing the power levels and exposure time or both, while, the reduction of their progeny markedly increased. At 200W power level, egg hatchability percentage on fababean seeds was 85.5 and $65.5 \%$ for 20 and 40 s, respectively. The hatchability of C. maculatus dropped to $0 \%$ at $600 \mathrm{~W}$ power level for 30 s exposure time or at $400 \mathrm{~W}$ and 40 s exposure, while the egg hatchability of the control sample on fababean was around $90-92 \%$. At $200 \mathrm{~W}$, the reduction of progeny of $C$. maculatus egg on fababean was 5.5 and $16.5 \%$ for 20 and 40 s, but it reached $100 \%$ at $600 \mathrm{~W}$ power level for $30 \mathrm{~s}$ or at $400 \mathrm{~W}$ for $40 \mathrm{~s}$ exposure time. For cowpea seeds, at 200W, 
egg hatchability was 74.5 and $53.6 \%$ for 20 and 40 s, respectively, while at $600 \mathrm{~W}$, the hatchability dropped to $0 \%$ for 20 s exposure time or at $400 \mathrm{~W}$ and 30 s exposure time. Meanwhile, the egg hatchability of the control sample on cowpea was around 90 $93 \%$. Moreover, the reduction of progeny of $C$. maculatus eggs on cowpea seeds at 200W was 9.5 and $20.8 \%$ for 20 and 40 s, respectively. While, the reduction of progeny reached $100 \%$ at power level of $600 \mathrm{~W}$ and 20 s exposure time or at $400 \mathrm{~W}$ power level for 30 s exposure time. The decrease in egg hatchability at higher power level or exposure time was due to the increase in temperature of the samples which affects the egg hatchability capacity as well as increasing the reduction of progeny of C. maculatus in the seeds. This result confirms that obtained by Bhalla et al., (2008).They revealed that the exposure of cowpea and green gram seeds infested with different life stages of $C$. maculatus to microwaves generated at frequency 2450 $\mathrm{MHz}$ with power level of $400 \mathrm{~W}$ for 70 s was effective against all the life stages of the pest.

\section{Mortality of adults and reduction of their progeny for life stages of $C$. maculates:}

The mortality of adults and reduction of progeny for larval, pupal and adults for $C$. maculates at various power levels and exposure time of infested fababean and cowpea seeds are shown in Figs. 4 and 5. It can be seen that the adult mortality and reduction of their progeny increased with increasing power levels and exposure times for two tested pulses. With an increase of power or exposure time, the temperature of the sample increased and consequently the mortality of adults and reduction of progeny of the insects were increased. The complete mortality for the adults in fababean obtained at $600 \mathrm{~W}$ for $30 \mathrm{~s}$ an exposure time or at $400 \mathrm{~W}$ for an exposure time of $40 \mathrm{~s}$ and corresponding to the mean surface temperature of the seeds around of 58 and $60^{\circ} \mathrm{C}$, respectively. The complete reduction of progeny of larval stage was also obtained at $600 \mathrm{~W}$ for $20 \mathrm{~s}$ or at $400 \mathrm{~W}$ for $30 \mathrm{~s}$ exposure time as for egg stage. While, one hundred percent reduction of progeny of $C$. maculatus pupal stages in fababean were achieved at $800 \mathrm{~W}$ for $20 \mathrm{~s}$ an exposure time and at $600 \mathrm{~W}$ for an exposure time of 30 s corresponding to mean surface grain temperature around of 55 and $58^{\circ} \mathrm{C}$, respectively. For cowpea seeds, the same trend was found for the mortality of adults and the reduction of progeny of the life stages of $C$. maculatus and there were higher at higher power levels and exposure time as obtained with the fababean seeds. While, the adult mortality and reduction of their progeny on cowpea seeds was slightly higher than that with fababean seeds. Among the life stages of $C$. maculatus in pulses, eggs were the most susceptible to the microwave energy followed by larval, adults and the least susceptible was the pupal. This may be due to the eggs being 
more directly exposed to microwave heating.While, larval and pupal stages being internal to the pulses seeds, were more insulated from the heat, experiencing a shorter exposure to lethal temperatures.These results are in agreement with those of Vadivambal et al., (2010) who used microwave energy at power level of 300, 400, 500 and $600 \mathrm{~W}$ to kill larval and adult stages of stored grain insects and reported that complete mortality was obtained at $500 \mathrm{~W}$ for $14 \mathrm{~s}$ or at $400 \mathrm{~W}$ for $28 \mathrm{~s}$. This result is also comparable to the results obtained by Johnson et al., (2011).

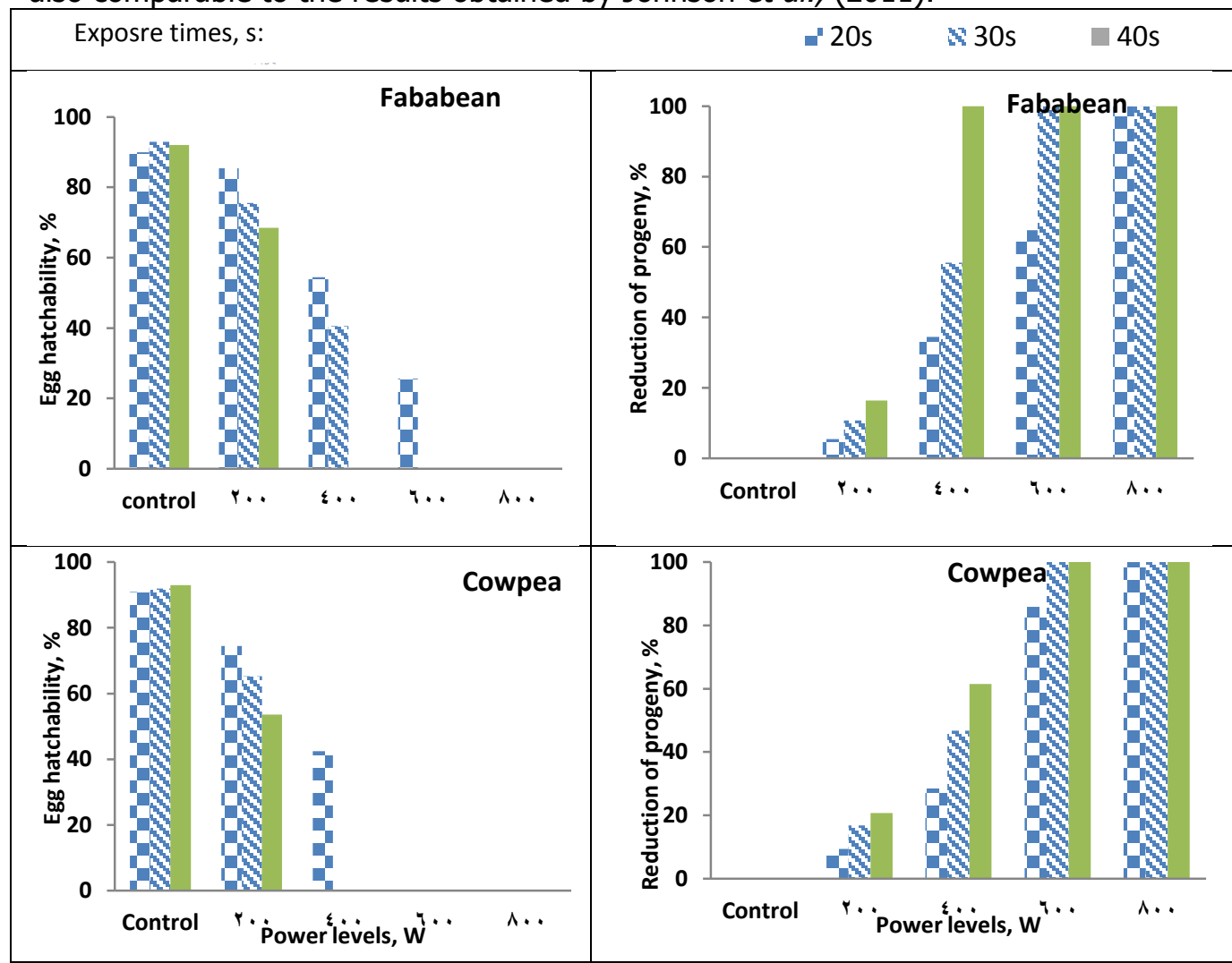

Fig. 3. Effect of microwave power levels on egg hatchability and reduction of their progeny of C. maculatus of infested fababean and cowpea seeds at various exposure times.

for an exposure time of 30s corresponding to mean surface grain temperature around of 55 and $58^{\circ} \mathrm{C}$, respectively. For cowpea seeds, the same trend was found for the mortality of adults and the reduction of progeny of the life stages of $C$. maculatus and there were higher at higher power levels and exposure time as obtained with the fababean seeds. While, the adult mortality and reduction of their progeny on cowpea seeds was slightly higher than that with fababean seeds. Among the life stages of $C$. maculatus in pulses, eggs were the most susceptible to the microwave energy followed by larval, adults and the least susceptible was the pupal. This may be due to the eggs being more directly exposed to microwave heating.While, larval and pupal stages being internal to the pulses seeds, were more insulated from the heat, experiencing a shorter exposure to lethal temperatures. These results are in agreement 
with those of Vadivambal et al., (2010) who used microwave energy at power level of $300,400,500$ and $600 \mathrm{~W}$ to kill larval and adult stages of stored grain insects and reported that complete mortality was obtained at $500 \mathrm{~W}$ for $14 \mathrm{~s}$ or at $400 \mathrm{~W}$ for 28s. This result is also comparable to the results obtained by Johnson et al., (2011). They conducted experiments to study time-mortality relationships for life stages of $C$. maculates at $50-60^{\circ} \mathrm{C}$ and concluded that larval were the most heat-tolerant stage. Exposure to microwave energy could cause physical injuries and reduce reproduction rates in surviving insects. For instance, treated larval may develop into adults with deformed or missing legs, although surviving insects were capable of reproduction. However, the reproduction rate decreased considerably. Also, Elzun et al., 2012 reported that complete mortality of all life stages of $\mathrm{C}$. maculatus was achieved after exposed the samples of infested cowpea seeds to microwave power level at $136 \mathrm{~W}$ for 360 s exposure time. From our results, it can be reported that, increasing power level from 136 to $400 \mathrm{~W}$ (2.8times), suggests reducing the seeds exposure time from $360 \mathrm{~s}$ to 30 s (by twelve times). Also, increasing power level from 136 to $600 \mathrm{~W}$ (4.4times) suggests reducing the seed exposure time from 360 s to 20 s (by eighteen times). Increasing the power level accelerates the disinfection process which leads to a considerable reduction in exposure time and consequently the time of seeds exposure to high temperatures was reduced as well as reduced the seeds quality losses.

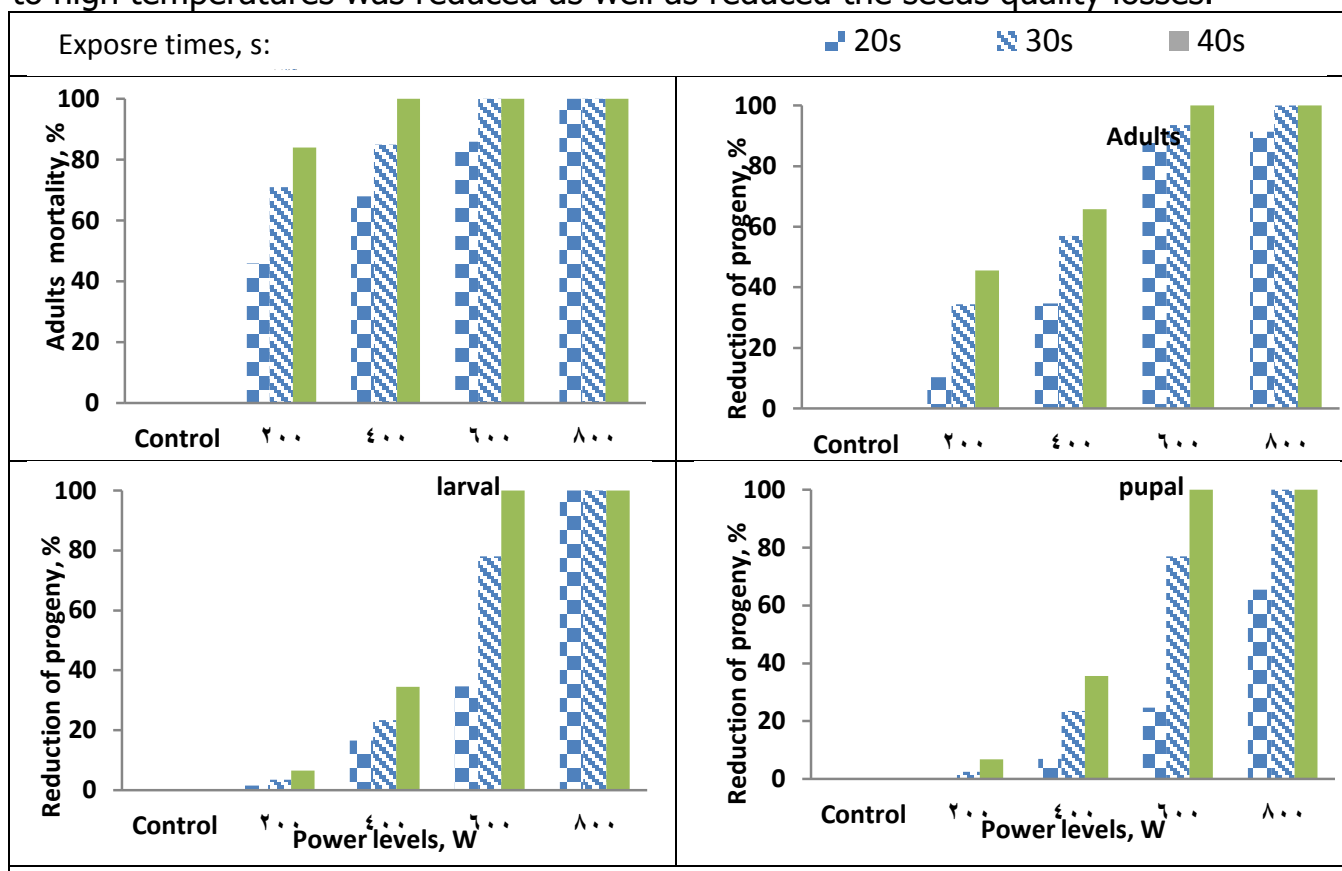

Fig. 4. Effect of microwave power levels on the adults mortality and their reduction of progeny of $C$. maculatus for infested fababean seeds at various exposure times. 


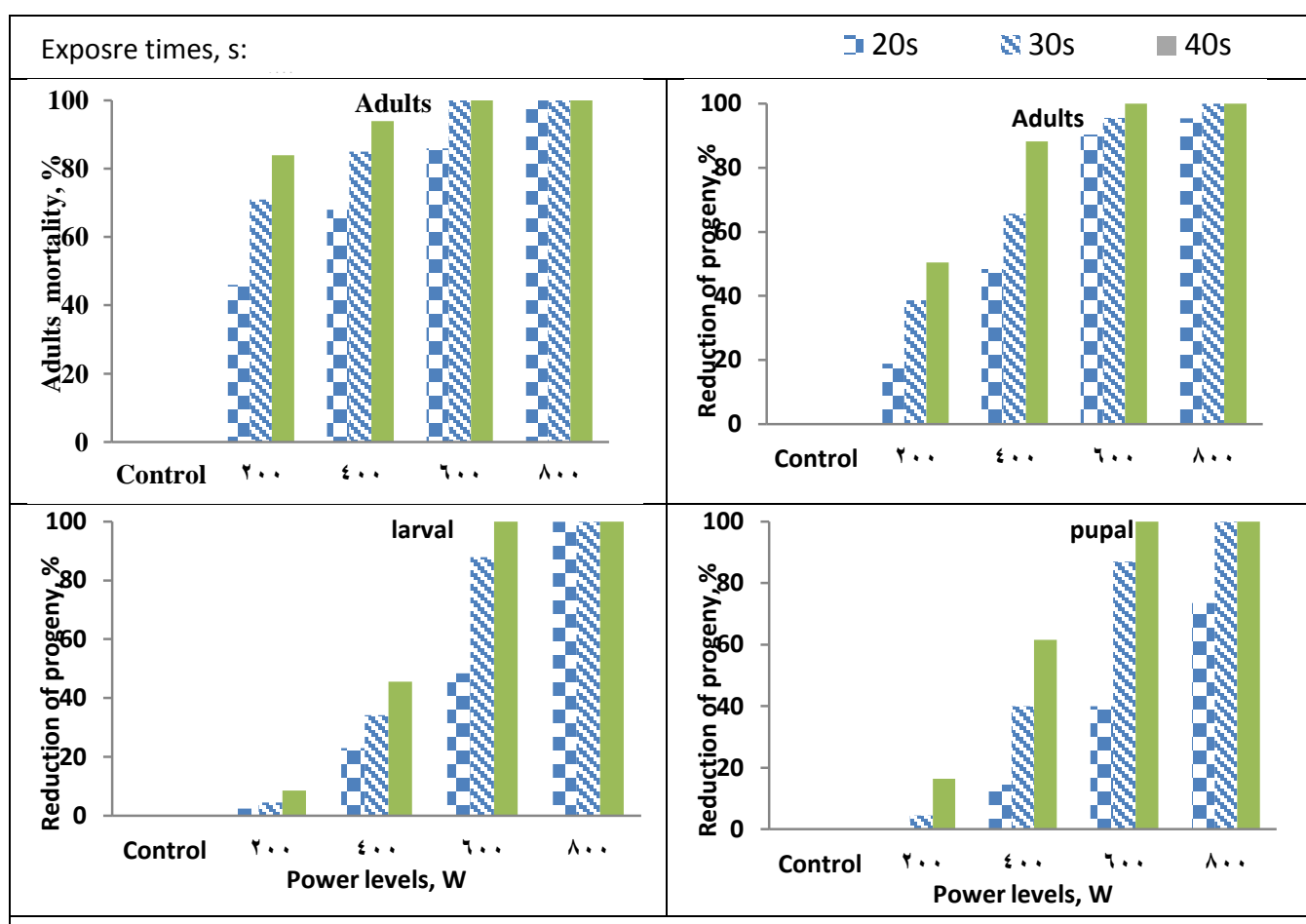

Fig. 5. Effect of microwave power levels on the mortality and their reduction of progeny of $C$. maculatus for infested cowpea seeds at various exposure times.

\section{Protein content:}

The pulses protein content for the control and treated samples at complete elimination of all life stages for $C$. maculatus was analyzed and the results are shown in Table 3. The results showed that there was no significant differences in the fababean and cowpea protein content of the control and treated samples at both power levels and exposure times as compared to control samples. Vadivambal et al., (2010) and Mohamed et al., (2011) also cleared that no significant difference in crude protein, oil and total carbohydrate percentage were evaluated in wheat and fababean seeds treated by microwave energy. Based on the data collected in the current study, it could be concluded that using microwave radiation is merit to be considered as a useful tool in stored-products insects control systems. The temperature reached during microwave heating for complete kill of insects was $55-59^{\circ} \mathrm{C}$, which lies within the safe limits suggested in the literature. These results are in agreement with other investigators who reported that low intensity microwave radiation had a little effect on food quality and wheat flour quality (Abo-El-Saad et al., 2011). Also, Lu et al., 2010 reported that microwave radiation and conductive heating were used to heat pest insects to lethal temperature while leaving the foodstuff in which they live unaffected or heated to a lesser extent than the insects themselves and completely kill Tribolium castaneum adult in wheat flour to protect the flour during storage without significantly affecting in its quality. 
Table 3. The pulses protein content for the control and treated samples.

\begin{tabular}{|c|c|c|}
\hline \multirow{2}{*}{ Treatments } & \multicolumn{2}{|c|}{ Protein content, \% } \\
\cline { 2 - 3 } & Fababean seeds & Cowpea seeds \\
\hline Control & $29.35 \pm 0.52 \mathrm{a}$ & $22.5 \pm 0.28 \mathrm{a}$ \\
400W, 30s & $29.25 \pm 0.34 \mathrm{a}$ & $22.4 \pm 0.25 \mathrm{a}$ \\
400W, 40s & $29.75 \pm 0.22 \mathrm{a}$ & $22.2 \pm 0.35 \mathrm{a}$ \\
$600 \mathrm{~W}, 20 \mathrm{~s}$ & $29.68 \pm 0.12 \mathrm{a}$ & $22.8 \pm 0.18 \mathrm{a}$ \\
$600 \mathrm{~W}, 30 \mathrm{~s}$ & $29.98 \pm 0.34 \mathrm{a}$ & $23.2 \pm 0.34 \mathrm{a}$ \\
$800 \mathrm{~W}, 20 \mathrm{~s}$ & $29.55 \pm 0.24 \mathrm{a}$ & $23.4 \pm 0.15 \mathrm{a}$ \\
\hline
\end{tabular}

In a column, means followed by the same letter are not significant at the $5 \%$ level.

\section{Germination results:}

The results of the germination tests conducted for fababean and cowpea at various power levels and exposure times was evaluated as shown in Fig. 6. As the power and exposure time increased, the germination of the two pulses was significantly lowered, while the cowpea seed was more sensitive to microwave heating than fababean seeds. At $200 \mathrm{~W}$, germination percentage of fababean was 81 and $67 \%$ for 20 and 40s, respectively. At $800 \mathrm{~W}$, the germination was 10 and $0 \%$ for exposure times of 20 and 40s, respectively. The germination of the control sample of fababean was around $89-92 \%$. Meanwhile, for cowpea seeds, the germination percentage was 73 and $57 \%$ for 20 and 40 s exposure time. The germination percent are slightly affected at 200W microwave power at lower exposure time. While, at $800 \mathrm{~W}$, the germination of cowpea was sharply decreased to 4 and $0 \%$ for exposure times of 20 and $40 \mathrm{~s}$, respectively, as compared to the germination of the control sample which around $79-82 \%$. Also, the germination of fababean was slightly higher than that of cowpea seeds at various treatments due to the increases of cowpea seed temperature more than fababean seeds at the same microwave treatment as well as due to the difference of size and shape of the seeds. The decrease in germination at higher power or exposure time was due to the increase in temperature of the sample which affects the germination capacity of the seed. Vadivambal, et al., (2010) also reported that germination of microwave treated corn decreased as power or exposure time or both was increased. 


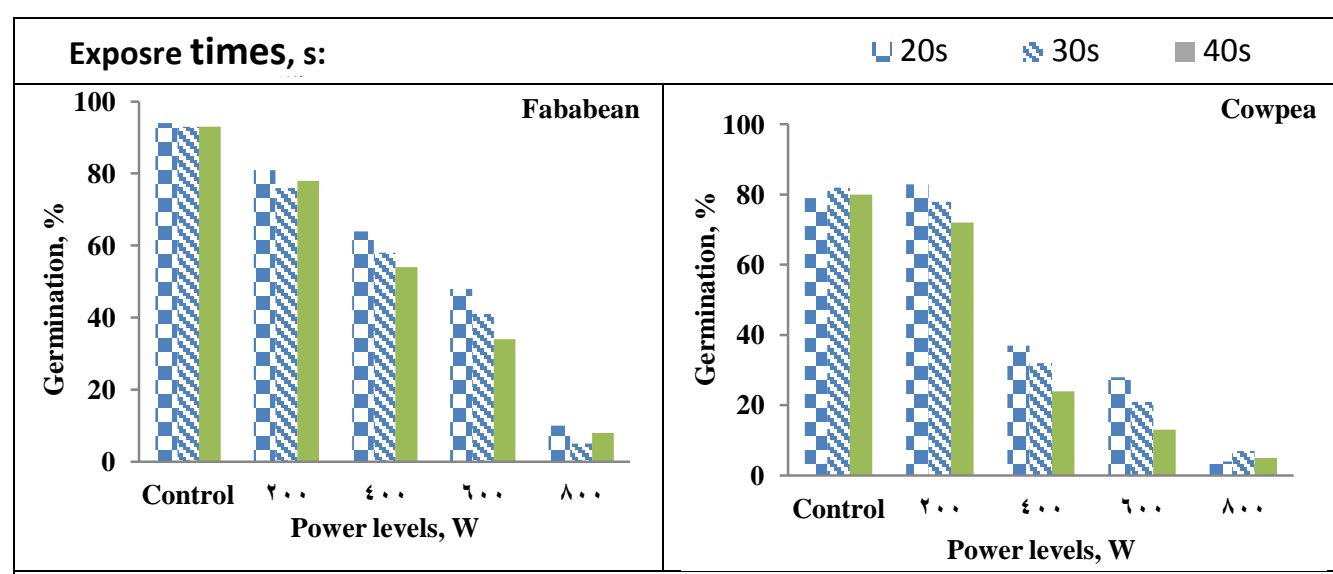

Fig. 6. Effect of microwave power levels on the germination of fababean and cowpea seeds at various exposure times.

\section{CONCLUSIONS}

1. The average surface temperature of cowpea and fababean seeds were around 52$60 \pm 1.5^{\circ} \mathrm{C}$ when complete mortality of $C$. maculatus all life stages was obtained.

2. The egg hatchability percentage decreased by increasing power level or exposure time, while the reduction of their progeny of all life stages markedly increased.

3. Mortality of C. maculatus all life stages were significantly higher at higher exposure time and power levels, while the mortality in infested cowpea seeds was higher than of fababean.

4. Among the life stages of $C$. maculatus in pulses, eggs were the most susceptible to the microwave energy followed by larval, adults and the least susceptible was the pupal.

5. Germination of fababean and cowpea seeds decreased significantly with increase in power level or exposure time or both, while there is no significant difference of protein content.

\section{RECOMMENDATIONS}

The information from this work could be used as a guideline for the design of disinfection process using microwave energy with exposure time of less than one minute, which can be used as an alternative method of chemical insect control because it does not seriously affect pulses quality. It is also important to transfer the technology from small scale laboratory models to actual large scale commercial implementation. Since only a major stored-pulse insect pest have been studied, other stored-pulses insect's mortalities could be studied. Determine the mortality of storage pests in other pulses using microwave energy and analyze their quality characteristics is needed. 


\section{REFERENCES}

1. Abo-El-Saad, M.M., H.A. Elshafie, A.M. Al Ajlan and I.A. Bou-Khowh. 2011. Nonchemical alternatives to methyl bromide against Ephestia cautella(Lepidoptera: Pyralidae): microwave and ozone. Agric. Biol. J. N. Am., 2(8): 1222-1231.

2. AOAC. 2005. Official Methods of Analysis of the Association of Official Analytical Chemists, 15th Ed, Arlington, Virginia USA.

3. Bhalla, S., K. Gupta, B. Lal, M.L. Kapur and R.K. Khetarpal. 2008. 0.41 - Efficacy of various non-chemical methods against pulse beetle, Callosobruchus maculatus Fab. ENDURE International Conference. Diversifying crop protection, 12-15 October La Grande-Motte, France-Oral presentations.

4. Elzun, H. M. N. A. El-Aidy and E. A. I. Mohamed. 2012. Effect of microwave energy on cowpea beetle (Callosobruchus maculatus Fabricius.), some chemical contents and viability of cowpea seeds. Mansoura Univ., 2(3): 283 - 294.

5. Guo, W., S. Wang, G. Tiwari, J. A. Johnson, and J. Tang. 2009. Temperature and moisture dependent dielectric properties of legume flour associated with dielectric heating. LWT-Food Sci. Tech. In press.

6. Johnson, J. A., S. Wang and J. Tang. 2011. Radio frequency heat treatments to disinfest dried pulses of cowpea beetle. USDA-ARS, Parlier, CA, Washington State University, Pullman: 76:1- 4.

7. Lu, H.H., J.C. Zhou, D. Yan, S.M. Zhao and S.B. Xiong. 2010. Effects of microwave radiation and conductive heating on Tribolium castaneum microstructure. Micron, 42: 36-41.

8. Mohamed, E. A., H. M. Elzun, N.A. El-Aidy and G. M. Zayed. 2011. Efficacy of microwave energy on: 1- cowpea beetle, Callosobruchus maculatus ( $f$ ), some of chemical contents and viability for fababean seeds. J. Plant Prot. and Pathology, Mansoura Univ., 2 (3): 283 -294.

9. Nishkaran G., 2002. Effect of fat content and food type on heat transfer during microwave heating. M. Sc. Thesis, Faculty of Virginia Polytechnic Institute and State University.

10. Shoughy, M. I. and M. I. Amer. 2006. Physical and mechanical properties of fababean seeds. Misr J. Ag. Eng., 23(2):434- 447.

11. Upadhyay, R.K. and S. Ahmad. 2011. Management strategies for control of stored grain insect pests in farmer stores and public warehouses. World J. Agric. Sci., 7(5): 527-549. 
12. Vadivambal, R. 2009. Disinfestation of stored grain insects using microwave energy. Ph. D Thesis. University of Manitoba, Winnipeg, Manitoba, Canada.

13. Vadivambal, R., D. S. Jayas and N. D. G. White. 2008. Mortality of stored-grain insects exposed to microwave energy. Trans. of The ASABE. 51(2): 641-647.

14. Vadivambal, R., O.F. Deji, D.S. Jayas, and N.D.G White. 2010. Disinfestation of stored corn using microwave energy. Agric. and Biology J. of North America 1, (1): $18-26$.

15. Varith, J. and T. Kiatsiriroa. 2004. Effects of microwave power, treatment time and sample orientation on heat distribution in mango. ASAE Paper No. 04-6104. ASAE/CSAE Annual International Meeting, Ottawa, Ontario, Canada, August 1-4.

16. Zaalouk, A. K. and T. H. Ghanem. 2003. Some physical and mechanical properties of cowpea seeds. Misr J. Ag. Eng., 20(2): 363-379.

17. Zia-UL-Haq, M., S. Ahmad, E. M. Chivard, and S. Ahmed. 2010. Studies of oil from cowpea (Vigna unguiculate (L.) Walp. cultivars commonly grown in Pakistan. Pak. J. Bot., 42(2): 1333-1341. 


\title{
القضاء علي خنفساء اللوبيا في بعض البقوليات المخزنه باستخدام طاقة الميكرويف
}

\author{
محمد اسماعيل شوغي! ، هشام مصطفى الظن \\ ا . . معهز بحوث الهنسة الزراعية - مركز البحوث النزراعية

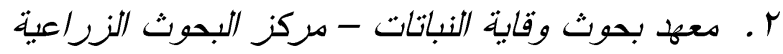

تعتبر البقوليات من أهم مصادر البروتين بسعر منخفض في مصر بصفه خاصه ودول العبر العالم الثالث.

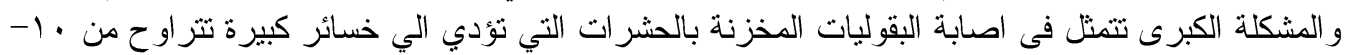

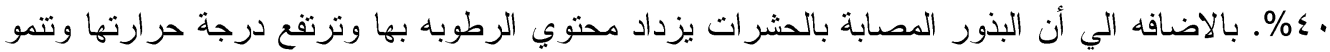

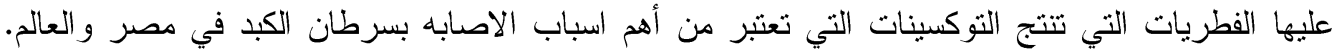

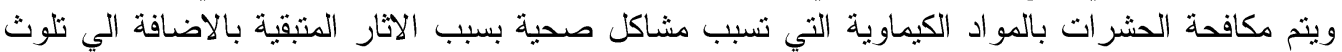

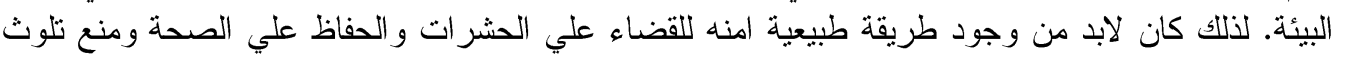

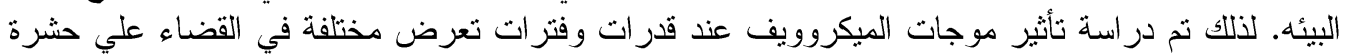

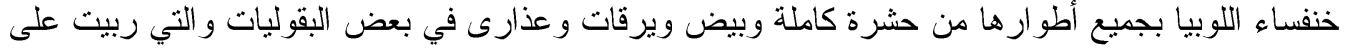

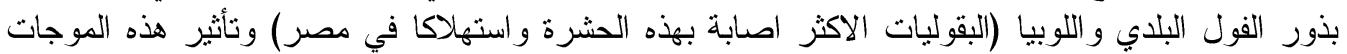

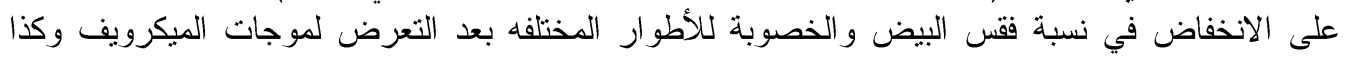

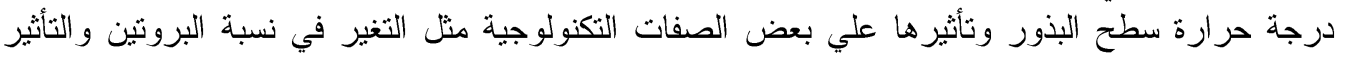
على نسبة الإنبات. ومن أهم النتائج ما يلي: الآنيات

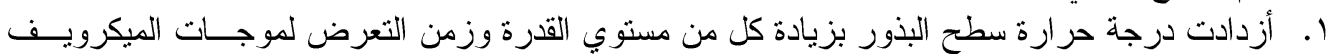

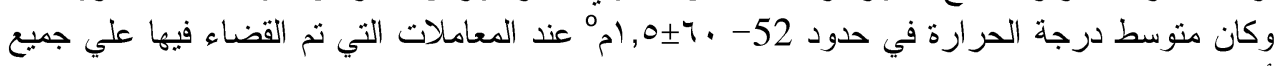

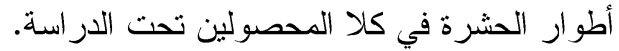

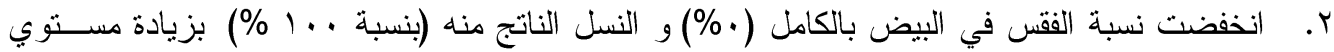

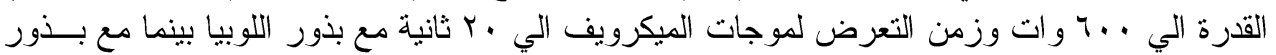

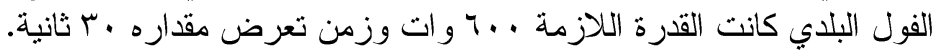

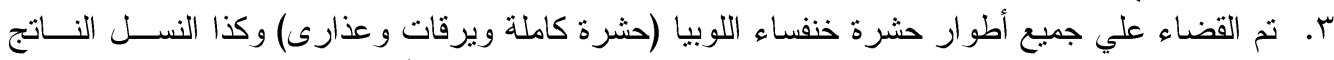

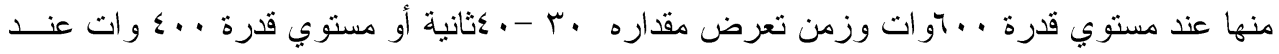

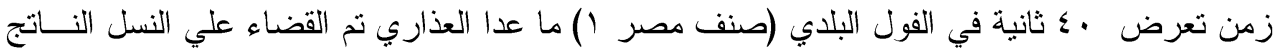

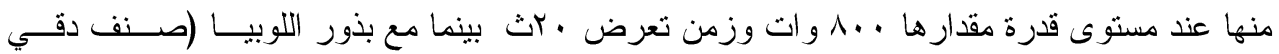

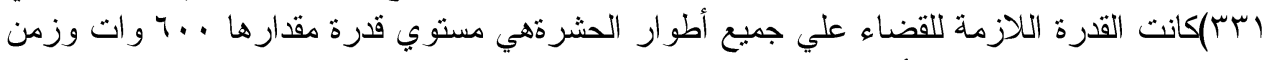

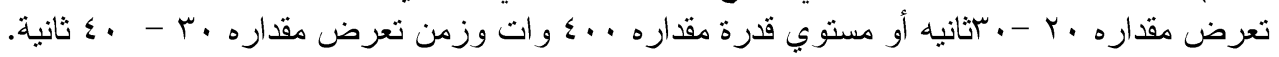

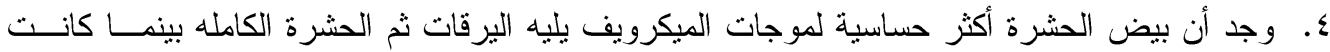

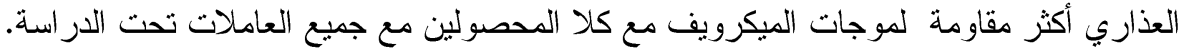

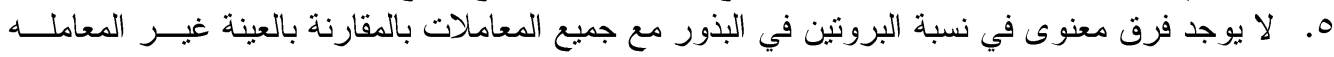

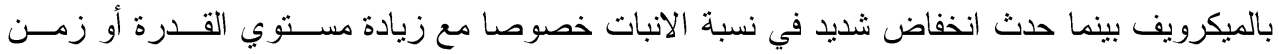

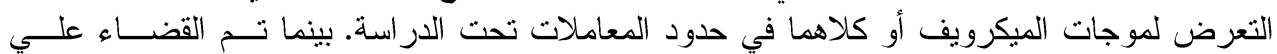
الحشرة بجميع أطو ارها في أقل من دقيقة.

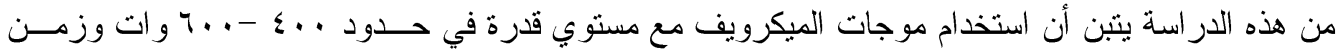

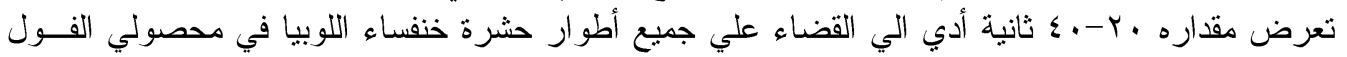

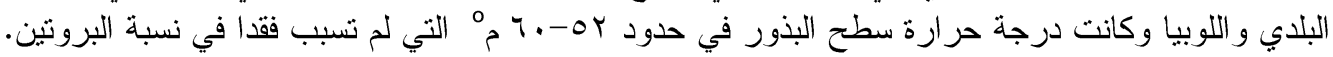

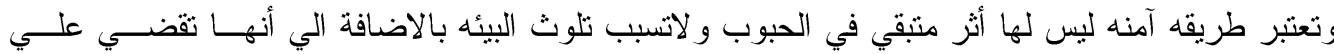

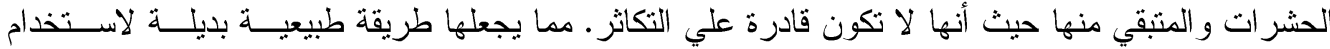

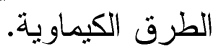

